\title{
Trophic ecology of two piranha species, Pygocentrus nattereri and Serrasalmus marginatus (Characiformes, Characidae), in the floodplain of the Negro River, Pantanal
}

\author{
Ecologia trófica de duas espécies de piranha, Pygocentrus nattereri e \\ Serrasalmus marginatus (Characiformes, Characidae), na planície de \\ inundação do Rio Negro, Pantanal
}

Fabiane Silva Ferreira ${ }^{1,2}$, Wagner Vicentin ${ }^{3}$, Fábio Edir dos Santos Costa ${ }^{4}$ and

Yzel Rondon Súarez ${ }^{2}$
'Programa de Pós-Graduação em Recursos Naturais, Universidade Estadual de Mato Grosso do Sul - UEMS, CEP 79804-970, Dourados, MS, Brazil e-mail: fabianesfbio@gmail.com

${ }^{2}$ Laboratório de Ecologia, Centro Integrado de Análise e Monitoramento Ambiental - CinAM, Universidade Estadual de Mato Grosso do Sul - UEMS, Rod. Dourados-Itahum, Km 12, CEP 79804-

970, Dourados, MS, Brazil

e-mail: yzel@uems.br

${ }^{3}$ Programa de Pós-Graduação em Ecologia e Conservação, Universidade Federal de Mato Grosso do Sul - UFMS, CEP 79070-900, Campo Grande, MS, Brazil e-mail: wagnervicentin.bio@gmail.com

${ }^{4}$ Laboratório de Ictiologia, Centro de Pesquisas em Biodiversidade - CPBio, Universidade Estadual de Mato Grosso do Sul - UEMS, CEP 79804-970, Dourados, MS, Brazil e-mail: fabioescosta@gmail.com

\begin{abstract}
Aim: This study aimed to evaluate influence of hydrological variation, ontogeny and interspecific variation in the feeding activity and diet composition for P. nattereri and S. marginatus in floodplain of Negro River, South Pantanal. Methods: The samples were taken with the use of gillnets and cast nets of different sizes, from October/2005 to August/2008. Results: We sampled 748 specimens, 442 of $P$. nattereri and 306 of $S$. marginatus. We identified 31 items in the dry and 14 in the flood season for P. nattereri, and 29 items in the dry and eight in the flood season for $S$. marginatus. For both species, fish was the predominant food item in both seasons. The PERMANOVA results showed that the diet varied significantly between the two species $(p<0.001)$, during ontogenetic development $(\mathrm{p}<0.001)$ and seasonally $(\mathrm{p}=0.024)$. The ancova results suggests that the intensity of food intake was higher in the dry season $(\mathrm{p}<0.001)$ for both species. The niche breadth varied only between studied species with $S$. marginatus presenting higher niche breadth than $P$. nattereri. Conclusion: Piranhas feed more during dry season, probably because in this period food is more varied and abundant, due to the concentration of fish in the main river channel. There were ontogenetic changes in the diet, with no feeding overlap between the two species, probably because of differences in preference for some items and differences in feeding behavior displayed during hunting attacks.
\end{abstract}

Keywords: Serrasalminae, diet, feeding overlap, trophic ontogeny, Nhecolândia.

Resumo: Objetivos: Este trabalho tem como objetivo avaliar a influência da variação hidrológica, da ontogenia e da variação interespecífica na atividade alimentar e composição da dieta de $P$. nattereri e $S$. marginatus na planície de inundação do Rio Negro, Pantanal Sul. Métodos: As amostragens foram realizadas com o uso de redes de espera e tarrafas com diversas malhagens no período de outubro/2005 e agosto/2008. Resultados: Foram coletados um total de 748 indivíduos, 442 de P. nattereri e 306 indivíduos de $S$. marginatus. Identificamos 31 itens alimentares no período da seca e 14 na cheia para $P$. nattereri e 29 itens alimentares no período da seca e oito na cheia para S. marginatus. Para ambas as espécies, peixes foi o item predominante em ambas as estaçóes. Os resultados da PERMANOVA mostraram que a dieta variou significativamente entre as espécies $(\mathrm{p}<0,001)$, durante o desenvolvimento ontogenético $(\mathrm{p}<0,001)$ e sazonalmente $(\mathrm{p}=0,024)$. Os resultados da ANCOVA sugerem que a intensidade da tomada de alimento foi maior na estação seca $(\mathrm{p}<0,001)$, para ambas as espécies. A amplitude de nicho 
variou entre as espécies estudadas, $S$. marginatus apresentou uma amplitude de nicho maior do que P. nattereri. Conclusáo: As piranhas se alimentam mais durante a seca, provavelmente porque neste período o alimento é mais variado e abundante, devido a concentração de peixes no canal principal do rio. Houve mudanças ontogenéticas na dieta, sem sobreposição alimentar entre as duas espécies, devido, provavelmente, as diferenças nas preferências e no comportamento de caça durante os ataques.

Palavra-chave: Serrasalminae, dieta, sobreposição alimentar, variação ontogenética, Nhecolândia.

\section{Introduction}

Studies on the feeding of fishes provide important information for a better understanding of the relationships between components of the ichthyofauna and other organisms of the aquatic community, and are an efficient approach to understand community structures (Polis and Winemiller, 1996). Knowledge of food sources used by fish may provide insight into the habitat, food availability in the environment and some aspects of behavior, while information about the intensity of food intake may be useful to complement studies of competitive interactions or resource partitioning among species (Schoener, 1974; Hahn et al., 1997). Understanding the trophic ecology of fish can help to elucidate ecological interactions such as inter- and intraspecific competition (Corrêa and Silva, 2010).

Although many fish species are specialists to a greater or lesser extent, their diet at a particular time will depend on the availability of typical or atypical items and on the presence of potential competitors (Moyle and Cech, 1988). Analysis of the diet of fish species in different seasons and during their ontogenetic development may improve understanding of the dietary breadth of species (Gerking, 1994) and how each species functions ecologically.

Pygocentrus nattereri Kner, 1858 and Serrasalmus marginatus Valenciennes, 1837 are piranhas, are widely distributed in rivers of the Pantanal, and are the most abundant predators in the Negro River (unpublished data). Both species are of medium size, with a high, strongly compressed body. They have a single row of teeth in each jaw and a serrated keel formed by spines on the belly (Britski et al., 2007). Piranhas are predators that feed chiefly on pieces of fins, scales and other body parts of their prey (Agostinho and Marques, 2001; Pompeu and Godinho, 2003; Costa et al., 2005).

The flood pattern is the main ecological phenomenon of the Pantanal, and the flooded area and water residence time determine the habitat and food availability for the fish, thus directly affecting their abundance (Catella and Petrere Junior, 1996).
During the high flood season in the rivers, the aquatic habitats become connected, allowing the fish to disperse in search of more favorable habitats. As shown by some studies (Poff and Allan, 1995; Ibarra et al., 2003), this dispersal affects the feeding dynamics of the community. The manner in which each species faces these changes is related to its feeding habit and feeding behavior. However, there is a lack of information on how piranhas in the Pantanal respond to the flood dynamics.

It is well known that $P$. nattereri and $S$. marginatus are species with similar, carnivorous/piscivorous feeding habits (Resende, 2000). The two species share the same habitat and are phylogenetically related (Hubert et al., 2007). Then this study aimed to evaluate influence of hydrological variation (dry vs flood period), ontogeny (size classes) and interspecific variation in the food intake and diet composition for $P$. nattereri and S. marginatus in floodplain of Negro River, South Pantanal.

\section{Material and Methods}

\subsection{Study area and fish sampling}

The Negro River is a typical floodplain river located in the central Pantanal. It is about $530 \mathrm{~km}$ long, from its headwaters in the Maracaju and Negra hills to its confluence with the Paraguay River (Mato Grosso do Sul, 2005). Its course forms the southern boundary of the region called Nhecolândia, Pantanal, which contains many and varied lakes and ponds in its floodplain. In the stretch where the fish were studied, the river is about $100 \mathrm{~m}$ wide and has its flood peak between February and April, when it reaches a depth of approximately $3.8 \mathrm{~m}$.

The samples were taken bimonthly during three years, from October 2005 through August 2008, in a stretch of about $10 \mathrm{~km}$ in the main channel of the Negro River upstream and downstream from the Rio Negro Farm (19 $35^{\circ} 20.04^{\prime \prime} S$ and $56^{\circ}$ 11' 4.19" W). The farm belongs to Conservation International, and was established as a Private Natural Heritage Reserve (Figure 1). 


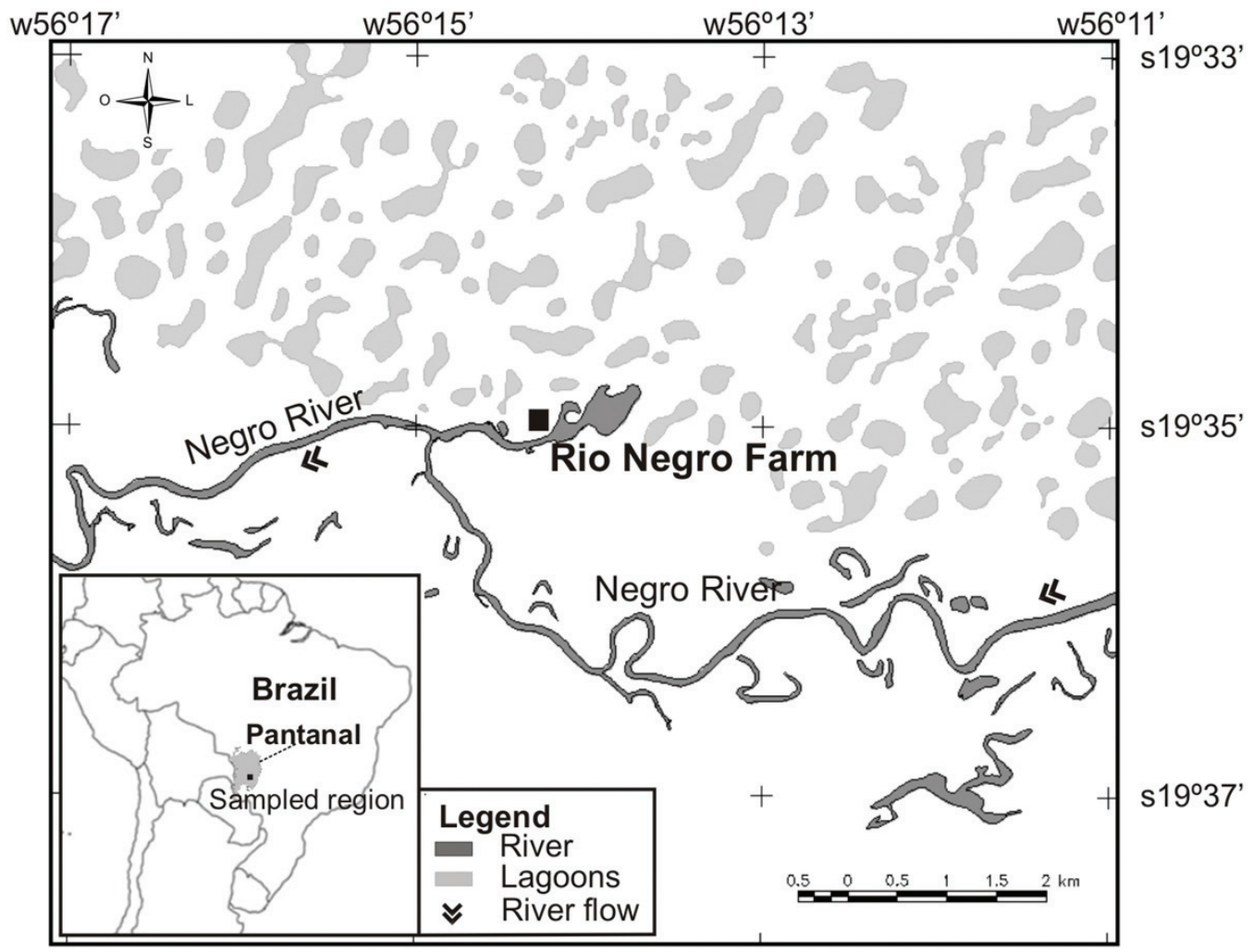

Figure 1. Location of the study area in the middle stretch of the Negro River, Nhecolândia region, Pantanal, Brazil.

The fish were captured by using a series of seven gillnets $(10 \times 1.5 \mathrm{~m}$ with mesh sizes between adjacent knots: $1.5,2.0,3.0,4.0,5.0,6.0,7.0)$ and 8 cast nets (height 1.5 to $3 \mathrm{~m}$, diameter 3 to $6 \mathrm{~m}$, and mesh sizes between adjacent knots: 1.5, 2.0, 2.5, 3.0, 4.0, $5.0,6.0,8.0$ ), for four days in each sampling event. This range of net sizes was used in order to sample different sizes of fish.

In the field, the sampled fishes were identified according to Britski et al. (2007). Of each fish were measured the standard length (SL) and stomach weight $(\mathrm{SW})$ using a precision balance $(0,01 \mathrm{~g})$. The stomachs were packaged in plastic bags, labeled and fixed in $10 \%$ formalin to posterior analysis in laboratory. The stomachs were analyzed with the aid of a stereomicroscope and the volume of each food item found in the stomach contents was measured by the water displacement in a graduated test tube.

\subsection{Data analysis}

\subsubsection{Diet composition}

For seasonal analysis the months of fish sampling along the whole period were grouped into dry and flood periods, using data of river level variation during the sampling period. Then October,
December and February were considered flood period and April, June and August were considered dry period. The standard length varied between $12.5-28.5 \mathrm{~cm}$ for S.marginatus and $10.0-32.0 \mathrm{~cm}$ for P.nattereri. For ontogenetic variation analysis, the values for standard length were divided into classes of $3 \mathrm{~cm}$.

To test the influence of interspecific, ontogenetic and hydrological period the items were grouped in six categories (Table 1) we used a Permutational Multivariate Analysis of Variance (PERMANOVA), according the function adonis in vegan package, $\mathrm{R}$ platform ( $\mathrm{R}$ Development Core Team, 2013). This procedure evaluates the mean distance among objects/groups, evaluating if the distances among analyzed individuals between the two piranha species, periods and size classes are greater than would occur by chance. Significant differences were considered as $\mathrm{P}<=0.05$, after 999 permutations.

The niche breadth was estimated using the levin's measure for each fish analyzed. We used a function niche.width in spaa package (R Development Core Team, 2013). The variation of niche breadth among studied species, hydrological period and size classes were quantified using a factorial analysis of variance. 
Table 1. Categories and food items recorded in the diets of Pygocentrus nattereri and Serrasalmus marginatus.

\begin{tabular}{cl}
\hline Categories & \multicolumn{1}{c}{ Food items } \\
\hline Plants & Plant fragments such as leaves, roots, sticks and seeds \\
Insects & Orders Coleoptera, Hymenoptera, Hemiptera and remains of unidentified insects \\
Scales & Fragments and whole scales of fish \\
Fishes & $\begin{array}{l}\text { Orders Characiformes, Siluriformes, Gymnotiformes, Synbranchiformes and remains of fish in advanced } \\
\text { stage of digestion such as muscles, spine and vertebrae }\end{array}$ \\
Fins & Remnants of fins \\
Mammals & Bats, fur of capybara and fur of unidentified mammals \\
\hline
\end{tabular}

\subsubsection{Feeding activity}

The influence of seasonal variation on the intensity of food intake was evaluated by Analysis of Covariance of the stomach weight (response variable) as a function of the month when the sample was taken (explanatory variable). The total weight was used as a co-variable. The data for total weight and stomach weight were previously converted in $\log _{10}$.

\section{Results}

In total, we captured 748 individuals, including 442 of Pygocentrus nattereri (weight: 49.0-1,200 g and length: $10.0-32.0 \mathrm{~cm}$ ) and 306 individuals of Serrasalmus marginatus (weight: 38.0-852.0 g and length: $12.5-28.5 \mathrm{~cm}$ ). One hundred twenty-eight stomachs $(28.9 \%)$ with contents were recorded for P. nattereri (69 stomachs in the flood period and 59 stomachs in the dry), and 98 stomachs (32.0\%) with contents for $S$. marginatus (29 stomachs in the flood period and 69 in dry period).

Twenty-nine food items were recorded in the dry season, and eight in the flood for $S$. marginatus and for $P$. nattereri, 31 items were recorded in the dry season, and 14 in the flood.

For both species, in both periods, the predominant category that showed higher volumetric frequency was fish. For $P$. nattereri, plants was the second most ingested category in both seasons. For $S$. marginatus, fins was the second most ingested category in the flood season, and in the dry, plants was the second one (Figure 2).

Fish of different orders comprised the main food category for both species. The predominant order was Characiformes, followed by Siluriformes in the flood and dry seasons for both species. Serrasalmus marginatus fed predominantly on individuals belonging to Curimatidae, which represented $10.87 \%$ and $20.26 \%$ of the diet in the dry and flood seasons, respectively. For $P$. nattereri, curimatids (Psectrogaster acantogaster) comprised $5.78 \%$ and $6.67 \%$ in the dry and flood seasons, respectively (Table 2).

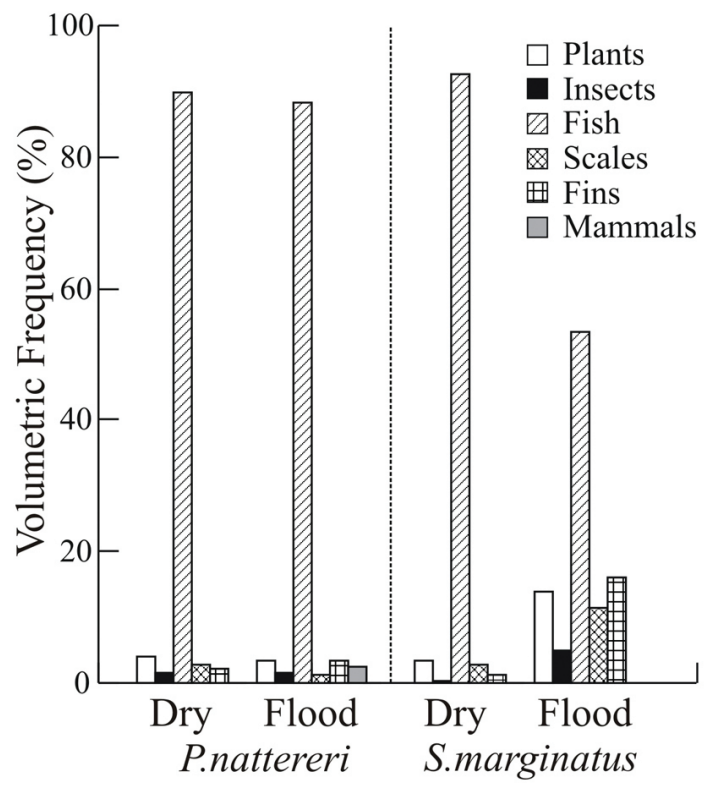

Figure 2. Volumetric frequency of food items in Pygocentrus nattereri and Serrasalmus marginatus, in the flood and dry seasons, in the Negro River, Nhecolândia region, Pantanal, from October 2005 through August 2008.

The volumetric frequency of food categories exploited by different size classes of $P$. nattereri showed that fish was the most abundant item in all size classes. Plants were an item that occurred in all size classes for $P$. nattereri. Insects were more frequent in the $12 \mathrm{~cm}$ size class for $P$. nattereri and decreased in the subsequent classes. In spite of scale decreasing from $12 \mathrm{~cm}$ size class, two stomachs were full of scale in the $30 \mathrm{~cm}$ size class, resulting in an increasing in this class. Fins occurred from 15 to $27 \mathrm{~cm}$ size classes, being more frequent in $21 \mathrm{~cm}$ size class. Mammals occurred in 15 and $27 \mathrm{~cm}$ size classes (Figure 3).

For $S$. marginatus there was not any individual in $12 \mathrm{~cm}$ size class and fish were also the most frequent item in all size classes. Plants occurred in three size classes. Insects occurred from 18 to $24 \mathrm{~cm}$ size classes and fins from 15 to $27 \mathrm{~cm}$ size classes. Scales, more frequent in $15 \mathrm{~cm}$ size class, exhibited 
Table 2. Details of the main fish orders identified to species level, according to the volumetric frequency of food items in Serrasalmus marginatus and Pygocentrus nattereri in the dry and flood seasons, caught in the Negro River, Nhecolândia region, Pantanal, from October 2005 through August 2008.

\begin{tabular}{|c|c|c|c|c|}
\hline \multirow[b]{2}{*}{ Food Item } & \multicolumn{2}{|c|}{ S. marginatus } & \multicolumn{2}{|c|}{ P. nattereri } \\
\hline & Dry $(\%)$ & Flood (\%) & Dry (\%) & Flood (\%) \\
\hline Characiformes (Total) & 36.59 & 37.92 & 43.04 & 33.58 \\
\hline Ascestrorhynchus pantaneiro & - & - & - & 2.08 \\
\hline Astyanax asuncionencies & 4.26 & - & 2.14 & - \\
\hline Ctenobrycon alleni & - & - & - & 0.91 \\
\hline Gymnocorymbus ternetzi & - & 0.26 & - & - \\
\hline Moenkhausia dichroura & - & - & 1.03 & - \\
\hline Piabucus melanostoma & 3.41 & - & - & - \\
\hline Serrasalminae & - & - & 0.04 & 0.03 \\
\hline Serrasalmus maculatus & - & - & - & 6.51 \\
\hline Serrasalmus marginatus & 3.20 & - & - & - \\
\hline Triportheus spp. & 2.56 & - & - & 0.78 \\
\hline Triportheus pantanensis & - & - & - & 2.60 \\
\hline Curimatidae & 10.87 & 20.26 & 0.30 & - \\
\hline Curimatella dorsalis & - & - & - & 2.34 \\
\hline Potamorhina squamoralevis & 0.64 & 0.26 & 0.04 & 6.51 \\
\hline Psectrogaster curviventris & - & - & 5.78 & 2.08 \\
\hline Remains & 11.64 & 17.14 & 33.70 & 9.72 \\
\hline Siluriformes (Total) & 14.20 & 4.42 & 24.24 & 21.65 \\
\hline Callichthyidae & 1.32 & 4.42 & - & 0.91 \\
\hline Callichthys callichthys & 1.28 & - & - & - \\
\hline Doradidae & 4.26 & - & - & 6.67 \\
\hline Loricariidae & 0.17 & - & 2.57 & 0.21 \\
\hline Hypoptopoma inexspectatum & 3.84 & - & - & - \\
\hline Hypostomus spp. & 1.28 & - & - & 2.60 \\
\hline Pimelodidade & 1.11 & - & - & 2.29 \\
\hline Remains & 0.94 & - & 21.67 & 8.96 \\
\hline Gymnotiformes (Total) & 3.67 & - & - & - \\
\hline Eigenmannia trilineata & 1.11 & - & - & - \\
\hline Remains & 2.56 & - & - & - \\
\hline Synbranchiformes (Total) & - & - & - & 2.08 \\
\hline Synbranchus marmoratus & - & - & - & 2.08 \\
\hline
\end{tabular}

a decreasing along ontogenetic development (Figure 3).

Considering the feeding niche breadth we observed that their values changed significantly only between species ( $F=11.59$; $p<0.001 /$ Figure 4$)$, then, we did not detect ontogenetic $(\mathrm{F}=0.10 ; \mathrm{p}=0.747)$ or seasonal variation $(\mathrm{F}=1.29 ; \mathrm{p}=0.257)$ and any factors interaction. Then $S$. marginatus have a niche breadth larger than P. nattereri (Figure 4).

Considering the PERMANOVA results, the main determinant of diet composition is the interspecific variation $(\mathrm{F}=6.97 ; \mathrm{p}<0.001)$, followed by fish size $(\mathrm{F}=4.81 ; \mathrm{p}<0.001)$ and seasonal variation $(\mathrm{F}=2.67 ; \mathrm{p}=0.024)$. Then each species and size classes use a different food items in each hydrological period.

Using the analysis of covariance, we found a significant variation $(\mathrm{p}=0.001)$ in the adjusted mean weight of stomachs during the entire sampling period, indicating a seasonal variation in the intensity of feeding activity. This activity was significantly more intense in the dry season for both P. nattereri $(\mathrm{p}=0.042)$ and $S$. marginatus $(\mathrm{p}=0.021)$ (Table 3 and Figure 5).

\section{Discussion}

Studies in different Brazilian rivers have reported that many piranha species exploit a wide variety of food items, including arthropods, fish, other 


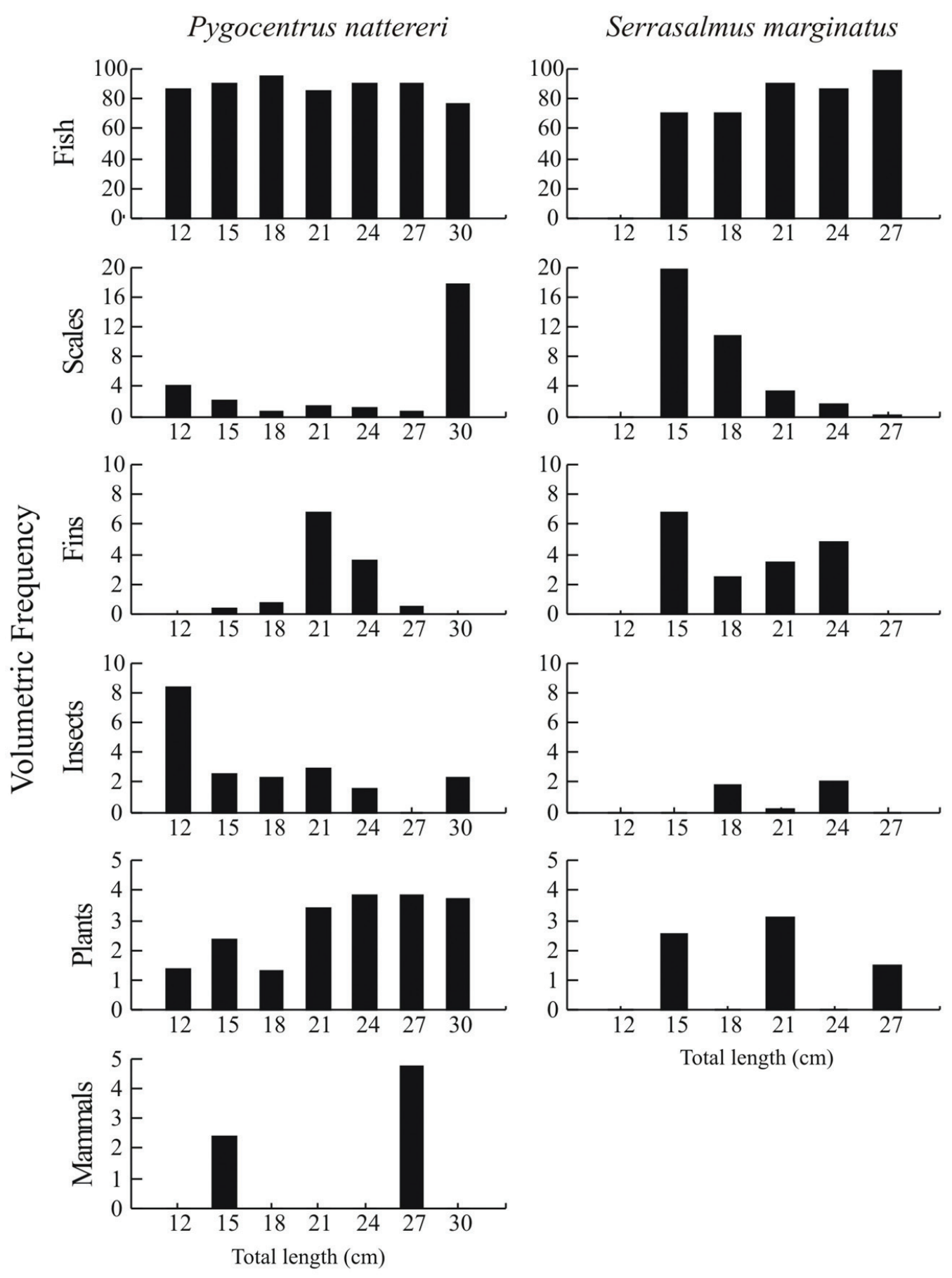

Fish size classes (TL)

Figure 3. Volumetric Frequency of food items by classes of total length of Pygocentrus nattereri and Serrasalmus marginatus caught in the Negro River, Nhecolândia region, Pantanal, from October 2005 through August 2008.

vertebrates, scales and plant remains (MachadoAllison and Garcia, 1986; Goulding et al., 1988; Sazima and Machado, 1990; Costa et al., 2005), although fish is the most preferred (Piorski et al., 2005; Trindade and Jucá-Chagas, 2008). Our results are in agreement with this statement, as we recorded a great variety of food items, and fish was the most predominant. Both piranha species studied here can be considered piscivorous predators, based on the predominance of whole fish or fish parts in their diets during the entire sampling period.

In spite of being piscivorous predators, plants were also registered in a great volumetric frequency of stomachs, as well as in studies of Nico and Taphorn 
(1988); Oliveira et al. (2004); Costa et al. (2005); Trindade and Jucá-Chagas (2008). Some authors reported that the intake of higher aquatic plants by piranhas is related to accidental intake during the predatory act (Machado-Allison and Garcia, 1986; Costa et al., 2005; Piorski et al., 2005; Behr and Signor, 2008). Similarly, Carvalho et al. (2007) in Pantanal wetland, attested that the predatory tactic employed by $P$. nattereri and $S$. maculatus, which consists of taking small bites of fish or other items on the water surface among aquatic macrophytes, may result in a high frequency of plant matter in the stomachs. It is possible that piranhas in the Negro river ingested plant accidentally as suggested by Carvalho et al. (2007), since in this region there is a great accumulation of macrophytes along the river and in the plain that contains many and varied lakes and ponds.

On the other hand, we may not discard the possibility of plants being actively taken during foraging, as related by Sazima and Machado (1990) on underwater behavior observation on piranhas in

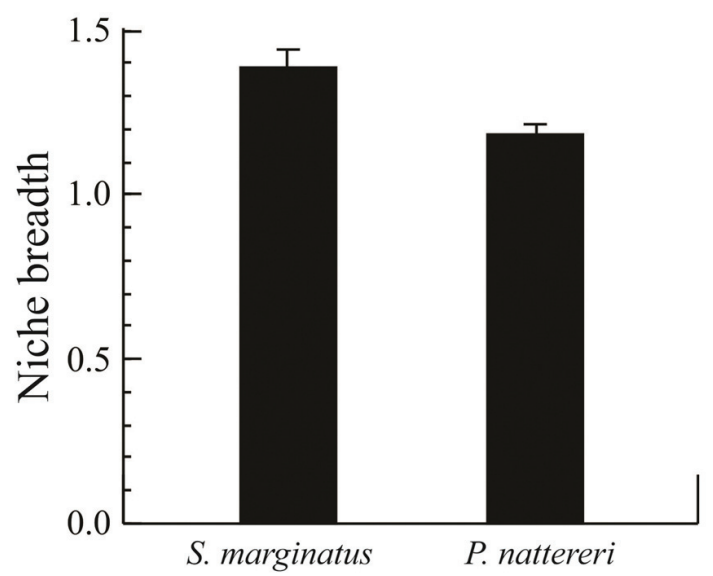

Figure 4. Values of niche breadth (mean \pm standard error) for Pygocentrus nattereri and Serrasalmus marginatus caught in the Negro River, Nhecolândia region, Pantanal, from October 2005 through August 2008. western Pantanal, since we were not able to apply observation methodology in this region. Another factor that needs to be considered is the inefficiency of carnivorous fish in digesting cellulose, which may result in the plant matter remaining longer in the stomach (Hildebrand, 1995), thus increasing the measurement of "relative importance" and frequently found as content in stomachs in all size classes of both piranhas.

The ingestion of fragments or whole individuals of insect, was also described by Sazima and Machado (1990); Resende et al. (1996); Behr and Signor (2008); Agostinho et al. (2003). They attest that the insects intake and other invertebrates in the diet of carnivorous fish is associated to the place and the time of the year and because of that, piranha species, as many of the tropical and subtropical fish species, may be considered polyphagous, ie,

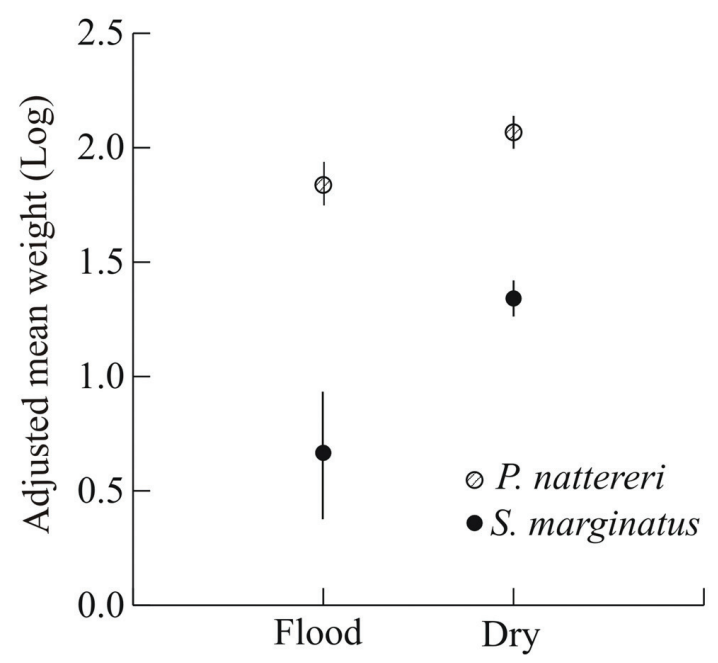

Figure 5. Analysis of covariance utilizing the total weight of stomachs as covariable for individuals of Pygocentrus nattereri and Serrasalmus marginatus caught in the Negro River, Nhecolândia region, Pantanal, from October 2005 through August 2008. Bars indicate standard error.

Table 3. Result of the Analysis of Covariance for the stomach weight for $S$. marginatus and P. nattereri in the Negro River Floodplain, Nhecolândia region, Pantanal from 2005 to 2008.

\begin{tabular}{|c|c|c|c|c|c|}
\hline ANCOVA & $\mathbf{N}$ & $\mathrm{r}^{2}$ & Mean & $F$ & $\mathbf{P}$ \\
\hline S. marginatus & 93 & 0.470 & & & \\
\hline Period & & & 2.941 & 5.508 & $0.021^{*}$ \\
\hline Total Weight & & & 40.470 & 75.796 & $0.001^{*}$ \\
\hline Residual & & & 0.534 & & \\
\hline P. nattereri & 119 & 0.427 & & & \\
\hline Period & & & 1.523 & 4.210 & $0.042^{*}$ \\
\hline Total Weight & & & 28.677 & 79.251 & $0.001^{*}$ \\
\hline Residual & & & 0.362 & & \\
\hline
\end{tabular}

${ }^{*}$ level of significance $\alpha=0.05 ; \mathrm{N}=$ sample size; $\mathrm{r}^{2}=$ coefficient of determination. 
they feed on diverse and available food, as insects, microcrustaceans and shrimps.

The behavior of feeding on parts of fish, such as muscles, scales or fins it is common for piranhas (Almeida et al., 1998). This kind of partial predation may be profitable for these fish predators (Winemiller, 1989; Almeida et al., 1998), because this strategy of not killing the preys may guarantee a fast and renewable source of food and fairly stable for piranhas (Northcote et al., 1987; Winemiller and Kelso-Winemiller, 1993; Nico and Morales, 1994).

The number of diet items was higher in $P$. nattereri when compared with $S$. marginatus. The larger number of individuals with stomach contents of $P$. nattereri (128 stomachs) may have contributed for this result in comparison with $S$. marginatus (98 stomachs), also as observed by Piorski et al. (2005) studying P. nattereri and Serrasalmus aff. brandtii.

Both species took in a greater diversity of food items in the dry than in the flood season. Nevertheless, we believe that this variety of items, integrated with higher stomach weight in dry season, might be related to the resource availability in the environment, as well as to a greater or lesser accessibility of particular items for the consumer. This is in agreement with the reports by Yamamoto et al. (2004) and Almeida et al. (1997) that the environmental seasonality controlled by the variation in water level may alter the richness and the abundance of resources in the environment, influencing the food intake and dietary composition of predator fish.

The PERMANOVA results indicated a significant difference in diet composition along ontogenesis, a seasonal variation for both species and no feeding overlap between both species. About these outcomes some points may be discussed. Although fish were predominant in the diet of all size classes of $P$. nattereri, specimens of smaller sizes fed mainly on fish, scale and insects, while specimens of greater sizes fed mainly on fish and plants. The diet of $S$. marginatus was based mainly on fish in all size classes. Scales and fins, more representative in the diet of smaller specimens, decreased in the greater size classes, demonstrating that this species becomes almost exclusively piscivorous in the last size class. Thus, for both species, despite the main feeding items (fishes) were maintained along ontogeny, the general diet change along ontogenesis was clear, as related to other piranha species (Pompeu, 1999; Agostinho et al., 2003; Casatti et al., 2003; Oliveira et al., 2004;
Piorsky et al., 2005). Nico and Taphorn (1988) at reporting that, piranhas are mutilators of fins and scales in smaller sizes and become predominantly piscivorous in greater sizes and this variation can be explained by morphological constraints, differences on habitat distribution along a size classes and energy demand.

A flexible diet is a remarkable feature of tropical fluvial ichthyofauna, the great majority of fish may change from a source to another as soon as the relative abundance of an item changes, motivated by spatio-temporal environmental changes (Abelha et al., 2001). Food availability in tropical environments, and mainly in floodplain rivers, varies widely between the dry and flood seasons. During the flood, the rising river level increases the abundance of food derived from the more different sources, providing better conditions for the fish to feed abundantly. In the dry season, the decrease in the water level leads to a scarcity of food (Resende et al., 1996). For carnivorous/piscivorous fishes this pattern may be inverted: during the flood stage, fodder fish species disperse over the floodplain in search of different food sources and shelter, which decreases their accessibility to predators. During the dry season, prey concentrate in the restricted water bodies and become more available to potential predators, thus increasing not only the diversity, but the abundance of these items. This is corroborated by the analysis of covariance, where stomachs were significantly heavier during the dry season for both piranha species, indicating that the feeding activity was more intense in dry season.

Among the predated species that could be identified in the stomach contents of the piranhas, members of Curimatidae were the most frequent. It cannot be determined if there is a preference for prey of this family, although their high abundance may make them relatively easy to catch. During the sampling of these two piranha species, other species of fish were also collected, showing that the curimatids Cyphocharax gilli, Potamorhina squamoralevis and Psectrogaster curviventris were among the five most abundant species in the region.

In spite of some shared items in the diet composition of the two piranha species, it was not found a niche overlap, suggesting that, in this sampled floodplain, occurs a resource partitioning between them. The main differences in diet composition between studied species are related to higher importance of fins and scales for $S$. marginatus when compared to $P$. nattereri, then, this important difference of food intake reduces the niche overlap 
and allows the coexistence of species, resulting in resource partitioning (Schoener, 1974). In this way, the sympatry of these species is possible as a response of diet differentiation. According to Brito (2007) and Brazil-Sousa et al. (2009) this differentiation can be explained by differential resource availability as consequence of spatial segregation.

Despite of $P$. nattereri presenting a higher number of prey types in diet composition, $S$. marginatus presented a higher niche breadth, then, besides of the difference in prey richness be smaller (31 and 29 prey types, respectively) the homogeneity in prey intake by $S$. marginatus may explain this difference in niche breadth estimation. The absence of significant variation in niche breadth along size classes and seasonal variations for studied species suggests that environmental variations alter the diet composition however did not interfere in trophic plasticity.

Despite others authors suggests that $P$. nattereri feeds more opportunistically on a wide variety of items (Sazima and Machado, 1990; Carvalho et al., 2007), our results showed that S. marginatus presented larger niche breadth, contradicting the hypothesis about its more specialized diet (Carvalho et al., 2007). The behavior of deploying the ambush strategy among the vegetation, in order to feed on pieces and scales of fish (Sazima and Machado, 1990) supports our results at showing scales and fins as secondary and important items in the diet of $S$. marginatus, on the other hand, insects were more common in the diet of $P$. nattereri. Thus, the distinctive ecological requirements of both piranha species and some preference on the secondary available items in the environment may contribute to preventing feeding overlap. Beyond that, our data suggest that differences in prey richness can be influenced by a number of stomachs with food, once the higher homogeneity in prey use lead a higher niche breadth in $S$. marginatus.

In view of these findings, we believe that in the floodplain of the Negro River, the wide variability of food items and the feeding flexibility of both species, chiefly with respect to the seasonality caused by the flood pulse, allied to different feeding behaviors during their ontogenetic development, may be fundamental in preventing feeding overlap of these two species.

\section{Acknowledgements}

The authors acknowledge the financial support of the Fundação de Apoio ao Desenvolvimento do Ensino, Ciência e Tecnologia do Estado de Mato
Grosso do Sul (FUNDECT) and of the Centro de Pesquisas do Pantanal (CPP/MCT). F. S. Ferreira is grateful for the student fellowship and logistic support provided by the Universidade Estadual de Mato Grosso do Sul (UEMS). W. Vicentin and F. S. Ferreira were supported by a student fellowship from the Coordenação de Aperfeiçoamento de Pessoal de Nível Superior (CAPES). Y. R. Súarez is supported by productivity grants from $\mathrm{CNPq}$. The authors are grateful to Vitor Simáo Galetti, Gabriela Serra do Vale Duarte, and Karina Tondato for their support in the laboratory and in the fieldwork.

\section{References}

ABELHA, MCF., AGOSTINHO AA. and GOULART, E. 2001. Plasticidade trófica em peixes de água doce. Acta Scientiarum, vol. 23, no. 42, p. 425-434.

AGOSTINHO, CS. and MARQUES, EE. 2001. Selection of netted prey by piranhas, Serrasalmus marginatus (Pisces, Serrasalmidae). Acta Scientiarium, Biological Sciences, vol. 23, no. 2, p. 461-464.

AGOSTINHO, CS., HAHN, NS. and MARQUES, EE. 2003. Patterns of food resource use by two congeneric species of piranhas (Serrasalmus) on the Upper Paraná River Floodplain. Brazilian Journal of Biology, vol. 63, no. 2, p. 177-182. PMid:14509839.

ALMEIDA, VLL., HAHN, NS. and VAZZOLER, AEAM. 1997. Feeding patterns in five predatory fishes of the high Parana river floodplain PR, Brazil. Ecology of Freshwater Fish, vol. 6, p. 123-133. http:// dx.doi.org/10.1111/j.1600-0633.1997.tb00154.x

ALMEIDA, VLL., HAHN, NS. and AGOSTINHO, CS. 1998. Stomach content of juvenile and adult piranhas (Serrasalmus marginatus) in the Paraná Floodplains, Brazil. Studies on Neotropical Fauna and Environment, vol. 33, p. 100-105. http://dx.doi. org/10.1076/snfe.33.2.100.2167

BEHR, ER. and SIGNOR, AA. 2008. Distribuição e alimentação de duas espécies simpátricas de piranhas Serrasalmus maculatus e Pygocentrus nattereri (Characidae, Serrasalminae) do rio Ibicuí, Rio Grande do Sul, Brasil. Iheringia, vol. 98, no. 4, p. 501-507. http://dx.doi.org/10.1590/S007347212008000400014

BRAZIL-SOUSA, C., MARQUES, RM. and ALBRECHT, MP. 2009. Food partitioning between two heptapterid fish species in Macaé River, RJ (Southeastern Brazil). Biota Neotropica, vol. 9, no. 3, p. 31-37. http://dx.doi.org/10.1590/S167606032009000300002

BRITO, MFG. 2007. Atividade reprodutiva dos peixes do rio Macaé (RJ) em função do gradiente longitudinal. Rio de Janeiro: Universidade Federal do Rio de Janeiro. 168 p. [Tese de Doutorado]. 
BRITSKI, HA., SILIMON, KZS. and LOPES, BS. 2007. Peixes do Pantanal: manual de identificaçáo. 2. ed. Brasília: Embrapa.

CARVALHO, LN., ARRUDA, R., RAIZER, J. and DEL-CLARO, K. 2007. Feeding habits and habitat use of three sympatric piranha species in the Pantanal wetland of Brazil. Ichthyological Exploration of Freshwaters, vol. 18, no. 2, p. 109-116.

CASATTI, L., MENDES, HF. and FERREIRA, KM. 2003. Aquatic macrophytes as feeding site for small fishes in the Rosana Reservoir, Paranapanema River, Southeastern Brazil. Brazilian Journal of Biology, vol. 63, no. 2, p. 213-222. PMid:14509843. http:// dx.doi.org/10.1590/S1519-69842003000200006

CATELLA, AC. and PETRERE JUNIOR, M. 1996. Feeding patterns of the fish community of Baía da Onça, a floodplain lake of the Aquidauana River, Pantanal, Brazil. Fisheries Management and Ecology, vol. 3, no. 3, p. 229-237. http://dx.doi. org/10.1111/j.1365-2400.1996.tb00150.x

CORRÊA, F. and SILVA, GC. 2010. Hábito alimentar de Astyanax asuncionensis (Géry, 1972) durante um período de seca e cheia, no Córrego do Onça, Coxim, Mato Grosso do Sul. Revista Brasileira de Biociências, vol. 8, no. 4, p. 368-372.

COSTA, AC., SALVADOR JUNIOR, LF., DOMINGOS, FFT. and FONSECA, ML. 2005. Alimentação da pirambeba Serrasalmus spilopleura Kner, 1858 (Characidae; Serrasalminae) em um reservatório do Sudeste brasileiro. Acta Scientiarium: Biological Sciences, vol. 27, no. 4, p. 365-369.

GERKIN, SD. 1994. Feeding ecology of fish. San Diego: Academic Press.

GOULDING, M., CARVALHO, ML. and FERREIRA, EG. 1988. Rio Negro: rich life in poor water. The Hague: SBC Academic Publishing. 200 p.

HAHN, NS., FUGI, R., ALMEIDA, VLL., RUSSO, MR. and LOUREIRO, VE. 1997. Dieta e atividade alimentar de peixes do reservatório de Segredo. In AGOSTINHO, AA. and GOMES, LC., eds. Reservatório de segredo: bases ecológicas para o manejo. Maringá: Eduem. p. 141-162.

HILDEBRAND, M. 1995. Análise da estrutura dos vertebrados. São Paulo: Atheneu.

HUBERT, N., DUPONCHELLE, F., NUN̈EZ, J., GARCIA-DÁVILA, C., PAUGY, D. and RENNO, JF. 2007. Phylogeography of the piranha genera Serrasalmus and Pygocentrus: Implications for the diversification of the Neotropical ichthyofauna. Ecologia Molecular, vol. 16, no. 10, p. 2115-2136. PMid:17498236. http://dx.doi.org/10.1111/j.1365294X.2007.03267.x

IBARRA, AA., GEVREY, M., PARK, YS., LIM, P. and LEK, S. 2003. Modelling the factors that influence fish guilds composition using a back-propagation network: assessment of metrics for indices of biotic integrity. Ecological Modelling, vol. 160, no. 3, p. 281-290. http://dx.doi.org/10.1016/S03043800(02)00259-4

MACHADO-ALLISON, A. and GARCIA, C. 1986. Food habits and morphological changes during ontogeny in three serrasalmin fish species of the Venezuelan floodplains. Copeia, no. 1, p. 193-195. http://dx.doi.org/10.2307/1444905

MATO GROSSO DO SUL. 2005. Relatório de qualidade das águas superficiais da Bacia do Alto Paraguai, MS, 2003. Campo Grande: Secretaria de Estado de Meio Ambiente e Recursos Hídricos/Instituto de Meio Ambiente Pantanal. 127 p.

MOYLE, PB. and CECH, JJJ. 1988. Fishes: an introduction to ichthyology. 2nd ed. Englewood Cliffs: Prentice-Hall. 559 p.

NICO, LG. and MORALES, M. 1994. Nutrient content of piranha (Characidae, Serrasalminae) prey items. Copeia, p. 524-528.

NICO, LG., and TAPHORN, DE. 1988. Food habits of piranhas in the low llanos of Venezuela. Biotropica, vol. 20, p. 311-321.

NORTHCOTE, TG., ARCIFA, MS., FROEHLICH, O. 1987. Fin-feeding by the piranha (Serrasalmus spilopleura Kner):the cropping of a novel renewable resource. In Proceedings of the V Congress of european Ichthyologists Stockholm, 1985. p. 133-143.

OLIVEIRA, AK., ALVIM, MCC., PERET, AC. and ALVES, CBM. 2004. Diet shifts related to body size of the pirambeba Serrasalmus brandtii Lütken, 1875 (Osteichthyes, Serrasalminae) in the Cajuru Reservoir, São Francisco River Basin, Brazil. Brazilian Journal of Biology, vol. 64, no. 1, p. 117-124. PMid:15195370. http://dx.doi.org/10.1590/S151969842004000100013

PIORSKI, NM., ALVES, JRL., MACHADO, MRB. and CORREIA, MMF. 2005. Alimentação e ecomorfologia de duas espécies de piranhas (Characiformes: Characidae) do lago de Viana, estado do Maranháo, Brasil. Acta Amazonica, vol. 35, no. 1, p. 63-70. http://dx.doi.org/10.1590/S004459672005000100010

POFF, NL. and ALLAN, JD. 1995. Functional organization of stream fish assemblages in relation to hydrological variability. Ecology, vol. 76, p. 606-627. http://dx.doi.org/10.2307/1941217

POLIS, GA. and WINEMILLER, KO. 1996. Food Webs: integration of patterns and dynamics. New York: Chapman \& Hall.

POMPEU, PS. 1999. Dieta da pirambeba Serrasalmus brandtii Reinhardt (Teleostei, Characidae) em quatro lagoas marginais do rio São Francisco, Brasil. Revista Brasileira de Zoologia, vol. 16, no. 2, p. 19-26.

POMPEU, PS. and GODINHO, HP. 2003. Dieta e estrutura das comunidades de peixes de três lagoas marginais do médio São Francisco. In GODINHO, 
HP. and GODINHO, AL., eds. Águas, peixes e pescadores do São Francisco das Minas Gerais. Belo Horizonte: PUC Minas. p. 183-194.

R Development Core Team. 2013. R: a language and environment for statistical computing. Vienna: $R$ Foundation for Statistical Computing.

RESENDE, EK. 2000. Trophic structure of fish assemblages in the lower Miranda River, Pantanal, Mato Grosso do Sul State, Brazil. Revista Brasileira de Biologia, vol. 60, no. 3, p. 389-403. PMid:11188865. http://dx.doi.org/10.1590/S003471082000000300004

RESENDE, EK., PEREIRA, RAC., ALMEIDA, VLL. and SILVA, AG. 1996. Alimentação de peixes carnivoros da planície inundável do rio Miranda, Pantanal, Mato Grosso do Sul, Brasil. Corumbá: Embrapa-CPAP. (Boletim de Pesquisa, no. 3).

SAZIMA, I. and MACHADO, FA. 1990. Underwater observations of piranhas in western Brazil. Environmental Biology of Fishes, vol. 28, no. 1-4, p. 17-31. http://dx.doi.org/10.1007/BF00751026

SCHOENER, TW. 1974. Resource partitioning in ecological communities. Science, vol. 185, no. 4145, p. 27-39. PMid:17779277. http://dx.doi. org/10.1126/science.185.4145.27

TRINDADE, MEJ. and JUCÁ-CHAGAS, R. 2008. Diet of two serrasalmin species, Pygocentrus piraya and Serrasalmus brandtii (Teleostei: Characidae), along a stretch of the rio de Contas, Bahia, Brazil. Neotropical Ichthyology, vol. 6, no. 4, p. 645-650.

WINEMILLER, KO. 1989. Ontogenetic diet shifts and resource partitioning among piscivorous fishes in the Venezuelan llanos. Environmental Biology of Fishes, vol. 26, no. 3, p. 177-199. http://dx.doi. org/10.1007/BF00004815

WINEMILLER, KO. and KELSO-WINEMILLER, LC. 1993. Fin-nipping piranhas. National Geographic Research \& Exploration, vol. 9, p. 344-357.

YAMAMOTO, KC., SOARES, MGM. and FREITAS, CEC. 2004. Alimentação de Triportheus angulatus (Spix \& Agassiz, 1829) no lago Camaleão, Manaus, AM, Brasil. Acta Amazonica, vol. 34, no. 4, p. 653659. 